\title{
Histamine and Cis-Urocanic Acid Augment Tumor Necrosis Factor-Alpha Mediated Induction of Keratinocyte Intercellular Adhesion Molecule-1 Expression
}

\author{
RAJ S. MITRA, YOJI SHIMIZU, AND BRIAN J. NICKOLOFF* \\ Departments of Pathology (R.S.M., B.J.N.) and Microbiology/Immunology (Y.S.), University \\ of Michigan Medical School, Ann Arbor, Michigan 48109-0602
}

\begin{abstract}
Early cellular and molecular events in inflamed skin include the active participation of epidermal keratinocytes (KCs) and dermal mast cells which can produce diffusible mediators such as tumor necrosis factor-alpha (TNF- $\alpha$ ), histamine, and urocanic acid (UCA). Rapid induction of adhesion molecules such as intercellular adhesion molecule-1 (ICAM-1) by KCs is observed following a highly diverse array of stimuli which can provoke both irritant, inflammatory, as well as allergic and immune reactions. To determine if the aforementioned mediators could interact in either an additive or synergistic fashion with each other, cultured KCs were exposed to these mediators alone and in combination, and the degree of ICAM-1 mRNA and protein quantitated. Whereas histamine or cis-UCA alone only weakly induced KC ICAM-1, when they were combined with TNF- $\alpha$, significant augmentation was observed by Northern blot hybridization studies, immunostaining, and FACS analysis. Other histamine derivatives such as L-histidine, 1-methylhistidine, 3-methylhistidine, or all-trans-UCA had no effect. Histamine pretreatment did not affect cell surface high affinity TNF- $\alpha$ receptors, as determined by ligand binding and immunodetection, and did not induce KC TNF- $\alpha$ production. The KC histamine receptor was also characterized and found not to be influenced by TNF- $\alpha$, cis-UCA, all-trans-UCA, or diphenyhydramine (an $\mathrm{H}_{1}$ antagonist), but it was inhibited by cimetidine ( $a n \mathrm{H}_{2}$ antagonist). These results demonstrate that 1) KCs can be induced to express ICAM-1 by exposure to histamine and cis-UCA, 2) histamine and cis-UCA can also augment TNF- $\alpha$ inducible ICAM-1 mRNA and cell surface protein expression, 3) this augmentation does not directly involve changes in KC TNF- $\alpha$ receptor number, affinity, or TNF- $\alpha$ production and, 4) KCs possess a type 2 histamine receptor which is not the photoreceptor for UCA. These findings highlight the potential for cross-talk between molecules produced by resident cutaneous cell types above (i.e., KCs) and below (i.e., mast cells) the epidermal basement membrane zone. These cells and their mediators can cooperate to respond to either exogenous or endogenous stimuli leading to rapid and strong KC ICAM-1 expression. Such induction of this important adhesion molecule by KCs ensures the retention of T lymphocytes necessary to participate in the maintenance of cutaneous immunohomeostasis. (c) 1993 Wiley-Liss, Inc.
\end{abstract}

In 1927 Sir Thomas Lewis proposed that the "triple response" of the skin following a wide variety of injurious stimuli was mediated by the appearance of a soluble product in the immediate neighborhood of affected epidermal cells that he termed the "H-substance" (Lewis, 1927). Ten years earlier, it had been demonstrated that histamine injection into human epidermis produced capillary dilatation and whealing. Eventually it was recognized that histamine was a potent local vasodilator, and that the $H$-substance and the mast cell derived histamine were identical (reviewed in Dale, 1929). In 1991, Barker et al. postulated that keratinocytes (KCs) could initiate cutaneous inflammation following a wide variety of injurious stimuli by their production of the cytokine, tumor necrosis factor-alpha
(TNF- $\alpha$ ). Thus, both mast cells and KCs may function as instigators of cutaneous inflammation via their production of diffusible molecular mediators. While there is a growing interest in the role of histamine in immu-

Received November 23, 1992; accepted March 22, 1993.

*To whom reprint requests/correspondence should be addressed.

Presented in part at the European Congress on Wound Healing and Skin Physiology, Bochum, Germany, November 5-7, 1992. An abstract (in an upcoming issue of Journal of Investigative Dermatology) describing this work has been accepted for presentation at the upcoming Annual Meeting of the Society of Investigative Dermatology, Washington, D.C., April 28, 1993. 
nological reactions, which complement its previous role in inflammation, there are relatively few reports that have explored the potential positive/negative interaction between histamine and immunomodulatory cytokines such as TNF- $\alpha$ (reviewed in Falus and Meretey, 1992). Also, another histamine related compound known as urocanic acid (UCA) has gained increasing attention for its immunomodulatory role in skin diseases (Noonan and DeFabo, 1992).

In this report, we asked whether there are any synergistic effects between histamine, UCA, and TNF- $\alpha$ with respect to the induction of $\mathrm{KC}$ intercellular adhesion molecule-1 (ICAM-1; CD-54) expression. KC ICAM-1 expression was chosen for study because it is rapidly induced (within 24-48 hr) in a variety of irritant and allergic contact dermatitis reactions (reviewed in Nick(loff, 1992). Moreover, following the epicutaneous application of the poison ivy antigen-urushiol, $\mathrm{KC}$ ]CAM-1 expression actually precedes any significant trafficking of bloodstream derived mononuclear leukocytes, suggesting that endogenously derived mediators produced by locally resident cutaneous cells are capable of triggering this epidermal immunomodulatory event (Griffiths and Nickoloff, 1989). In this report, we demonstrate that histamine or cis-UCA can directly induce a relatively low level of KC ICAM-1 expression, but when histamine or cis-UCA is combined with TNF- $\alpha$, both further augment the induction of ICAM-1.

\section{MATERIALS AND METHODS KC culture}

Using a Castroveijo keratome, primary $\mathrm{KC}$ cultures were obtained from normal-appearing skin of healthy adult volunteers without any skin disease and not on any medication. All volunteers gave written informed consent, with approval by the Human Subjects Comrnittee of the University of Michigan. A single cell suspension was prepared as previously described (Griffiths et al., 1989). Freshly isolated epidermal cells were seeded into $35 \mathrm{~mm}$ polystyrene tissue culture dishes (Corning Glass Works, Corning, NY) and grown in the presence of a low calcium $(0.15 \mathrm{mM})$ serum free medium containing epidermal growth factor (EGF, $10 \mathrm{ng}$ / $\mathrm{mal})$, insulin $(5 \mu \mathrm{g} / \mathrm{ml})$, hydrocortisone $(0.5 \mu \mathrm{g} / \mathrm{ml})$, and bovine pituitary extract $0.4 \% \mathrm{v} / \mathrm{v}$, designated KGM (Clonetics Corporation, San Diego, CA). Culture dishes were incubated in a humidified atmosphere containing $5 \% \mathrm{CO}_{2}$ at $37^{\circ} \mathrm{C}$ and the $\mathrm{KCs}$ were routinely passaged by using $0.03 \%$ trypsin $/ 0.01 \%$ ethylenediaminetetraacetic acid (EDTA) to disperse the semiconfluent monolayer of cells, and used between passage numbers 2 and 3.

\section{Treatments of KC cultures}

Semiconfluent $\mathrm{KC}$ cultures were always used for treatment with histamine (and its derivatives) or TNF- $\alpha$, and the treatment was continued for $48 \mathrm{hr}$. Recombinant human TNF- $\alpha$ was obtained from Genentech Inc., South San Francisco (specific activity $=1.7 \times 10^{7} \mathrm{U} / \mathrm{mg}$ ); histamine, L-histidine, 1-methylhistidine, and 3-methylhistidine were purchased from Sigma Chemical Corp., St. Louis, MO. The concentration of histamine or TNF- $\alpha$ is stated in the appropriate table or figure. Bioactivity and detection of TNF- $\alpha$ in conditioned medium which can detect as little as 10 $\mathrm{pg} / \mathrm{ml}$ were measured by cytolysis of WEHI cells (courtesy of Dr. D. Remick; University of Michigan) as previously described (Eskandari et al., 1990). All-trans-UCA was purchased from Sigma. Cis-UCA was prepared by ultraviolet-B (UV-B) irradiation of the trans-isomer. Briefly, $3 \mathrm{ml}$ of a $5 \mathrm{mg} / \mathrm{ml}$ stock solution of all-transUCA was placed into a $60 \mathrm{~cm}$ Petri dish and UV-B irradiated using a bank of four Westinghouse FS-40 fluorescent lamps at a distance of $1 \mathrm{~cm}$ above the dish. The intensity of the UV-B at the level of the liquid was measured using a radiometer (International Light Inc., Newburgport, MA). Under these conditions, the light source delivered over a 30 -min irradiation interval a total UV-B dose of $300 \mathrm{~mJ} / \mathrm{cm}^{2}$. While there was no detectable cis-UCA initially as determined using paper chromatography (Baden et al., 1966), after irradiation there were approximately equal amounts of cis-UCA and trans-UCA, as previously described (Ross et al., 1986). The irradiated solution was stored at $4^{\circ} \mathrm{C}$, and periodically checked by paper chromatography to verify the presence of cis-UCA. For each result, the concentration of cis-UCA was determined by dividing the initial all-trans-UCA concentration in half.

\section{Cell immunostaining}

To analyze constitutive expression and induction of ICAM-1 (anti-ICAM-1 monoclonal antibody [mAb] RR1/1; gift of Dr. T. Springer, Boston, MA) and class II major histocompatibility complex (MHC) (anti-HLA-DR mAb; L243; Becton-Dickinson, Mountain View, CA) on cultured cells by the various treatments, cells were detached from plastic dishes using $0.03 \%$ trypsin $/ 0.01 \%$ EDTA, with indirect immunofluorescence staining, followed by fluorescence-activated cell sorter (FACS) analysis as previously described (Griffiths et al., 1989). Antibody against the $55-60 \mathrm{kDa}$ form of the TNF- $\alpha$ receptor was obtained from Genzyme Corp., Boston, MA. Isotype control (Leu $2 \mathrm{a}, \mathrm{IgG}$; Becton-Dickinson) immunoreactivity was also measured. In addition to FACS analysis of single cell suspension, KCs were grown in 8-well tissue culture chamber slides (Lab-Tek, Nunc Inc., Naperville, IL). After various treatments, cell monolayers were fixed with cold acetone for $10 \mathrm{~min}$, air dried at room temperature, and then stained for ICAM-1 using a sensitive avidin-biotin-peroxidase technique (Vectastain Kit, Vector Laboratories, Burlingame, CA) as described previously (Griffiths and Nickoloff, 1989).

\section{Northern blot hybridization}

RNA from monolayers of untreated or treated $\mathrm{KC}$ was extracted with guanidine hydrochloride $(5.7 \mathrm{M})$, potassium acetate $(100 \mathrm{mM}, \mathrm{pH} 5.0)$, sonicated on ice for $60 \mathrm{sec}$, ethanol precipitated, and centrifuged at $15,000 \mathrm{~g}$ for $30 \mathrm{~min}$ at $4^{\circ} \mathrm{C}$ as previously described (Barker et al., 1990). Ten to $15 \mu \mathrm{g}$ total cellular RNA was separated on $1 \%$ agarose gels containing $2.2 \mathrm{M}$ formaldehyde and electroblotted on nytran membranes (Schleicher and Schuell, Keene, NH). The cDNA probe for ICAM-1 was cloned by differential hybridization as described elsewhere (Eskandari et al., 1990), and the cDNA probe for TNF- $\alpha$ was purchased from American Type Culture Center, Rockville, MD. Cyclophilin 
cDNA probe (obtained from C. Griffiths, University of Michigan) was used to measure constitutive gene activity because it is known to be minimally altered in cultured KCs (Barker et al., 1990). Each insert was purified by agarose gel electrophoresis and electroelution and ${ }^{32} \mathrm{P}$ labeled by the random primer method. Nytran membranes were hybridized overnight, washed in 0.3 M sodium chloride, $0.03 \mathrm{M}$ sodium citrate, and $1 \%$ sodium dodecyl sulfate (SDS) at $65^{\circ} \mathrm{C}$ and subjected to autoradiography. The results indicated are representative of blots obtained in three separate experiments using KCs isolated from different donors. The relative density of the signals from each lane of the Northern blots was determined by scanning laser densitometry as previously described for the quantitation of mRNA (Barker et al., 1990).

\section{Ligand binding assay}

${ }^{125}$ I-rTNF- $\alpha$ was purchased from New England Nuclear (NEN) Research Products, Wilmington, DE (specific activity, $44.9 \mu \mathrm{Ci} / \mu \mathrm{g}$ ). In a standard binding assay, approximately $2-2.5 \times 10^{5}$ untreated or histamine and/or TNF- $\alpha$ treated $\mathrm{KCs}$ in 24-well plates were washed twice with $\mathrm{KBM}$ at $37^{\circ} \mathrm{C}$ over a 3 -hr time interval. The cells were washed once with Earle's balanced salt solution (EBSS) containing $1 \%$ bovine serum albumin (binding assay medium) (radioimmunoassay [RIA] grade, Sigma). The cells were chilled on ice bath and then incubated with $0.5 \mathrm{ml}$ of binding assay medium and varied concentrations of ${ }^{125} \mathrm{I}-\mathrm{TNF}-\alpha(0.015-0.525$ $\mathrm{nM})$. The cultures were maintained at $4^{\circ} \mathrm{C}$ for the duration of binding assay (usually $4 \mathrm{hr}$ unless otherwise specified). The binding assay was terminated by washing the monolayers three times with ice-cold binding medium. Solubilization of cells was accomplished using $1 \mathrm{ml}$ of $0.1 \mathrm{~N}$ sodium hydroxide containing $1 \%$ SDS and counted in a gamma counter. Nonspecific binding was determined by adding 200 -fold excess of unlabeled TNF- $\alpha$ to parallel sample wells and was no greater than $25 \%$ of the total amount bound under any treatment conditions. Data points represent the average of duplicate samples with nonspecific binding subtracted. Each figure represents the mean of three separate experiments.

The uptake of labeled histamine by untreated or TNF- $\alpha$ treated cells was measured by following the published procedure (Haddock et al., 1987). Tritiumlabeled histaine hydrochloride (specific activity $=26.4$ $\mathrm{Ci} / \mathrm{mmol}$ ) was purchased from NEN Research Products. Cells were incubated at $37^{\circ} \mathrm{C}$ for $2 \mathrm{hr}$ with $0.038 \mu \mathrm{M}$ $\left[{ }^{3} \mathrm{H}\right]$ histamine in KGM medium containing $20 \%$ fetal bovine serum. Incubation was terminated by chilling on ice and washing the monolayer three times with cold Dulbecco's phosphate-buffered saline. Solubilization of the cells was accomplished using $0.25 \mathrm{~N}$ sodium hydroxide followed by liquid scintillation counting. To study the effect of histamine receptor antagonists on cellular uptake of histamine, cells were exposed to cimetidine and diphenhydramine (Sigma) at the indicated concentration shown in Table 1. A stock solution of $0.1 \mathrm{M}$ cimetidine in 50\% dimethyl sulfoxide (DMSO) or $0.1 \mathrm{M}$ diphenhydramine was prepared in KGM. Each was diluted just before use with KGM to give appropriate concentration.
TABLE 1. [ $\left.{ }^{3} \mathrm{H}\right]$ histamine uptake by cultured keratinocytes in the presence of various agents 1

\begin{tabular}{|c|c|}
\hline Agents used $(\mu \mathrm{M})$ & $\begin{array}{l}\text { Cell-associated } \\
\text { radioactivity }(\mathrm{dpm})\end{array}$ \\
\hline $0.038\left[{ }^{3} \mathrm{H}\right]$ histamine & $20,232 \pm 1,035$ \\
\hline \multicolumn{2}{|l|}{ + unlabeled histamine } \\
\hline 5 & $13,752 \pm 1,573$ \\
\hline 50 & $7,259 \pm 1,128$ \\
\hline 200 & $5,911 \pm 919$ \\
\hline 500 & $4,372 \pm 855$ \\
\hline $\begin{array}{l}+24 \mathrm{hr} \text { pretreatment with } \mathrm{TNF}-\alpha \\
(500 \mathrm{U} / \mathrm{ml})\end{array}$ & $18,821 \pm 1,872$ \\
\hline \multicolumn{2}{|l|}{+ diphenhydramine } \\
\hline 5 & $19,291 \pm 1,122$ \\
\hline 50 & $17,594 \pm 1,214$ \\
\hline 200 & $16,107 \pm 1,327$ \\
\hline 500 & $15,879 \pm 1,428$ \\
\hline \multicolumn{2}{|l|}{+ cimetidine } \\
\hline 5 & $16,128 \pm 1,275$ \\
\hline 50 & $11,126 \pm 987$ \\
\hline 200 & $7,552 \pm 873$ \\
\hline 500 & $6,102 \pm 799$ \\
\hline \multicolumn{2}{|l|}{+ trans-UCA } \\
\hline 5 & $19,355 \pm 1,750$ \\
\hline 50 & $18,811 \pm 1,383$ \\
\hline 200 & $19,943 \pm 1,412$ \\
\hline 500 & $18,837 \pm 1,329$ \\
\hline \multicolumn{2}{|l|}{+ cis-UCA } \\
\hline 5 & $18,569 \pm 1,437$ \\
\hline 50 & $17,918+1,328$ \\
\hline 200 & $20,203 \pm 1,265$ \\
\hline 500 & $18,365 \pm 1,353$ \\
\hline
\end{tabular}

${ }^{1} \mathrm{KCs}$ (approximately 450,000$)$ were incubated with $0.038 \mu \mathrm{M}\left({ }^{3} \mathrm{H}\right)$ histamine $\left(0.9 \times 10^{6}\right.$ $\mathrm{dpm}$ ) for $2 \mathrm{hr}$ at $37^{\circ} \mathrm{C}$ and cell associated radioactivity was determined as described in the Materials and Methods section. The concentration of various agents used is indicated. The results represent the mean of three separate experiments.

\section{RESULTS \\ Induction of KC ICAM-1 detected by immunostaining}

The potential ability of histamine to induce $\mathrm{KC}$ ICAM-1 was screened by performing immunostaining of intact semiconfluent monolayers. In the absence of any addition to the KGM medium, only a rare isolated KC (less than 1 of 100 cells) was ICAM-1 positive (Fig. 1a). Upon addition of TNF- $\alpha(50 \mathrm{U} / \mathrm{ml} ; 48 \mathrm{hr})$, numerous KCs became ICAM-1 positive (Fig. 1b). When KC cultures were exposed to $5 \mathrm{mM}$ histamine, there was also an increase in the number of ICAM-1-positive cells (Fig. 1c), which was substantially increased when a combination of TNF- $\alpha$ plus histamine was used (Fig. 1d). These positive direct $\mathrm{KC}$ responses to histamine led us to explore the potential ability of other histamine derivations to induce ICAM-1, either alone, or in combination with a low concentration of TNF- $\alpha$. There was no induction of KC ICAM-1 by L-histidine, 1-methylhistidine, 3-methylhistidine, or all-trans-UCA when used as a single agents (data not shown).

In the presence of TNF- $\alpha$, these same three compounds failed to either inhibit or increase in an additive or synergistic manner KC ICAM-1 expression. However, when a UV-B irradiated $5 \mathrm{mM}$ solution of alltrans-UCA was used (which contained approximately a

Fig. 1. Intact KC monolayers immunostained for ICAM-1 expression. KCs were maintained for $48 \mathrm{hr}$ in either KGM alone (A), or supplemented with $50 \mathrm{U} / \mathrm{ml} \mathrm{TNF}-\alpha(B), 5 \mathrm{mM}$ histamine (C), or TNF- $\alpha$ plus histamine (D). 


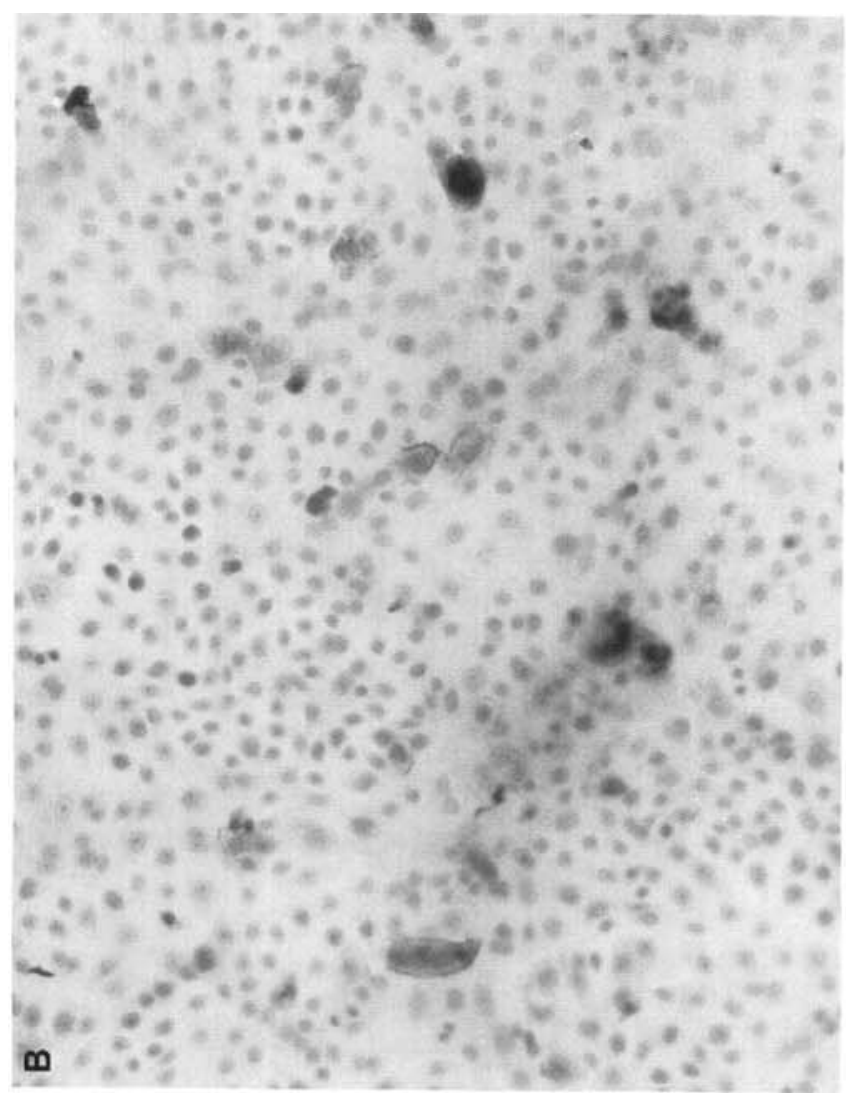

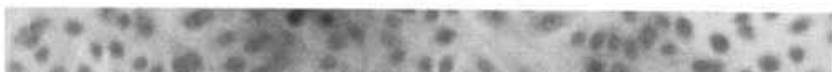

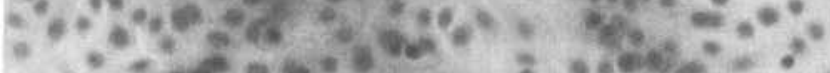

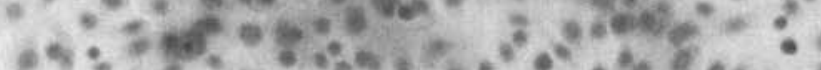

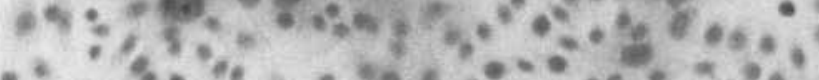

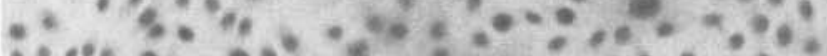

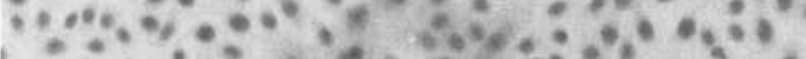

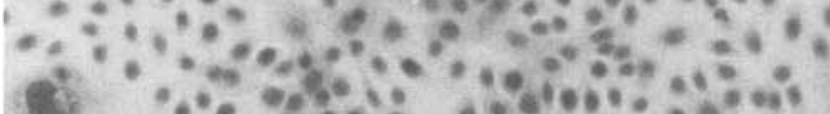

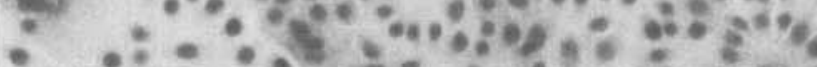

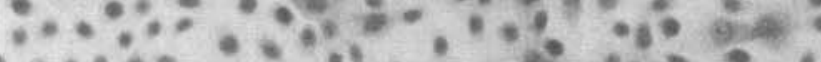

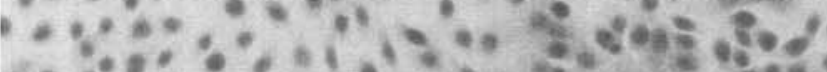
d:

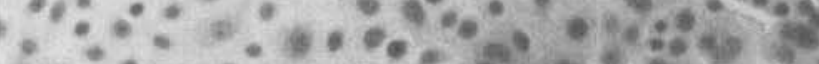

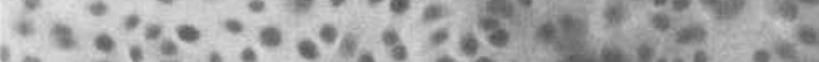

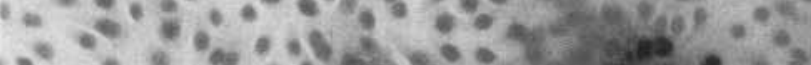

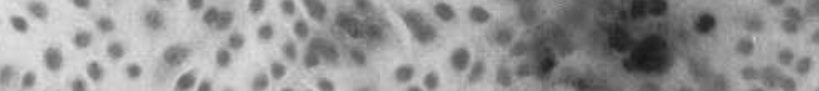

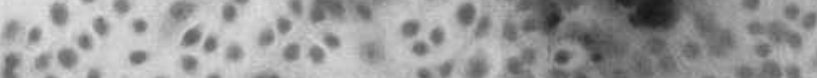

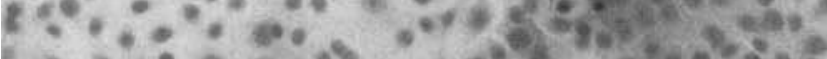

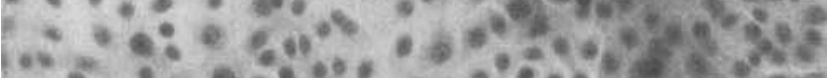

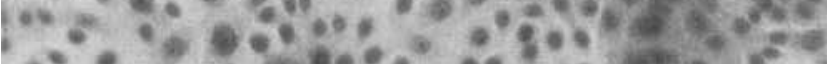

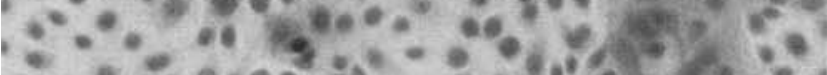

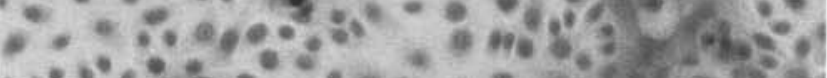
40000

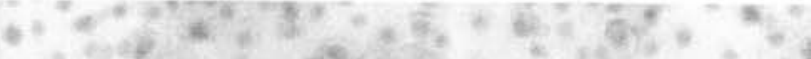

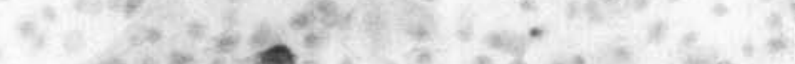

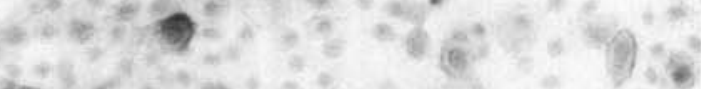

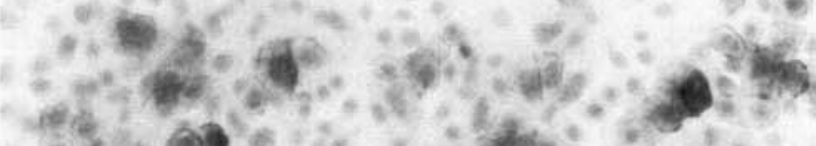

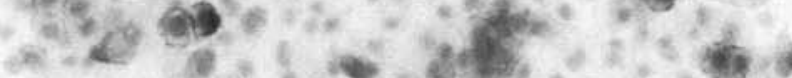

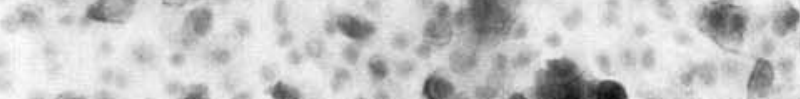

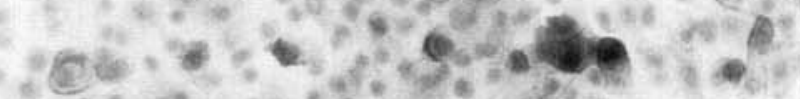

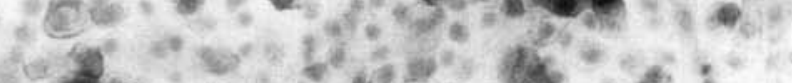

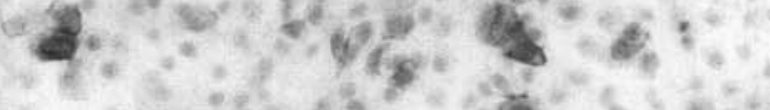

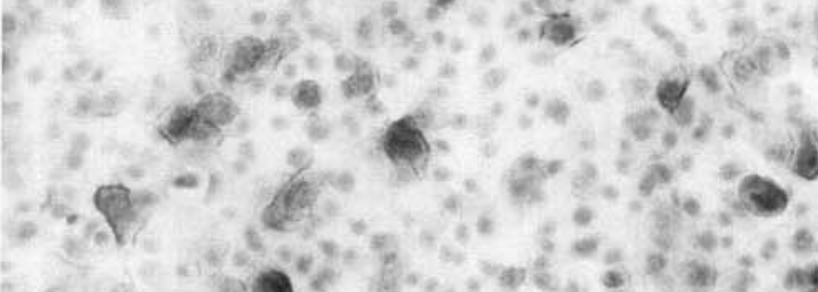

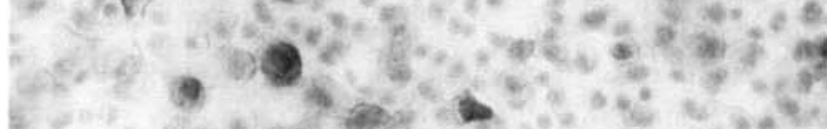

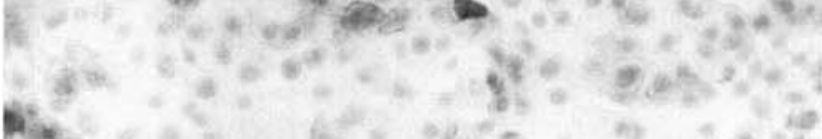
Pis.

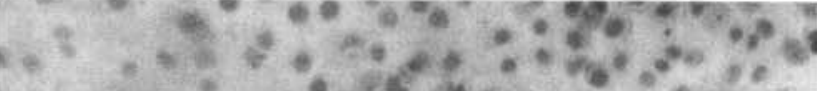

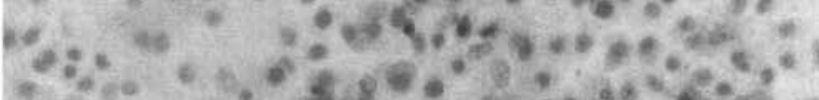

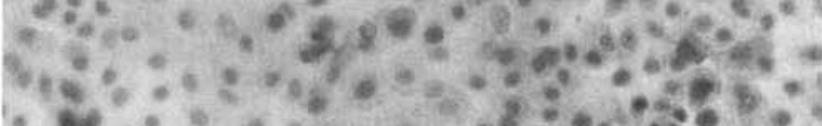

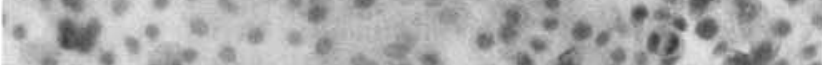

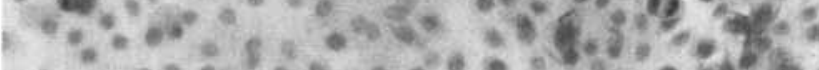

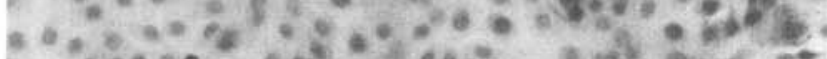

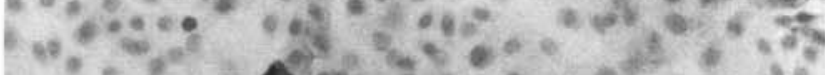

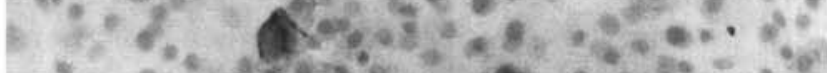

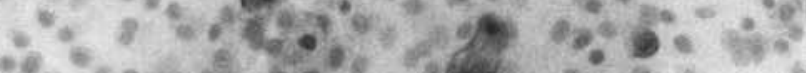

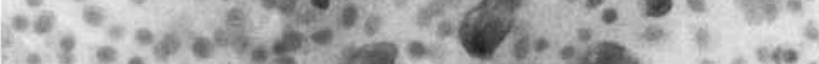

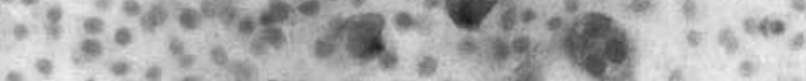

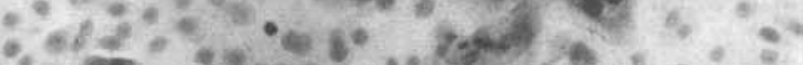

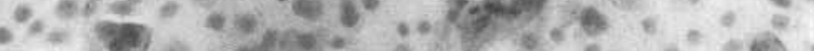
(2)

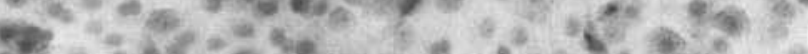

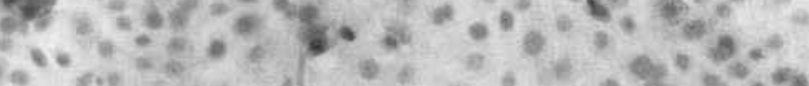

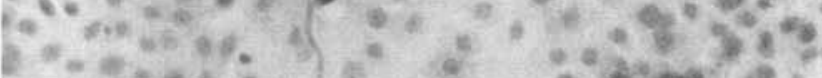

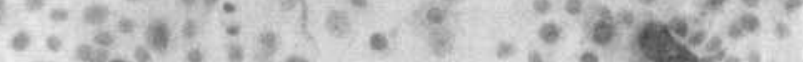

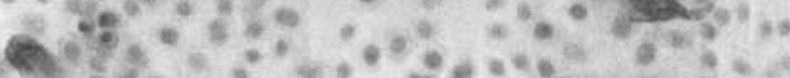

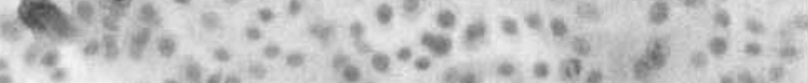

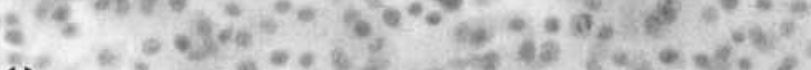

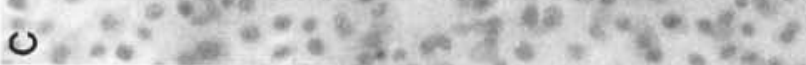




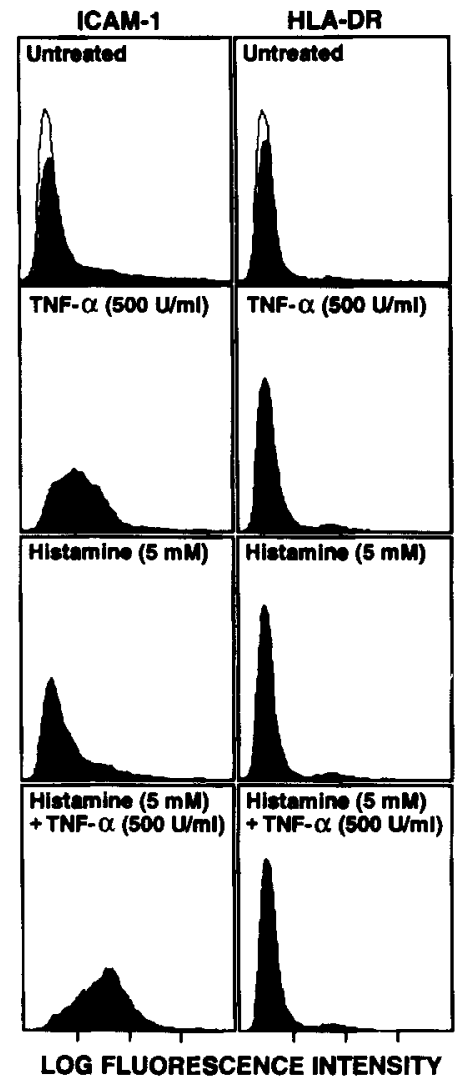

Fig. 2. FACS profile of KCs expressing ICAM-1, but not HLA-DR after $48 \mathrm{hr}$ exposure with either KGM alone (untreated), TNF- $\alpha$ (500 $\mathrm{U} / \mathrm{ml})$, histamine ( $5 \mathrm{mM})$, or histamine plus $\mathrm{TNF}-\alpha$.

$50 \%$ mixture of cis-UCA), KC ICAM-1 was induced in a similar manner as histamine (data not shown). To quantitate more precisely these aforementioned results, single cell suspensions were prepared and cell surface expression determined by FACS analysis.

\section{Induction of KC ICAM-1 by FACS analysis}

Figure 2 reveals a representative FACS analysis for KCs treated for $48 \mathrm{hr}$ with either KGM alone; TNF- $\alpha$ $(500 \mathrm{U} / \mathrm{ml})$; histamine $(0.5 \mathrm{mM})$; and the combination of TNF- $\alpha(500 \mathrm{U} / \mathrm{ml})$ plus histamine $(0.5 \mathrm{mM})$. The solid profile areas reveal that there is a synergistic induction of KC ICAM- 1 by the combination of TNF- $\alpha$ plus histamine, compared to the results using these molecules singly, in agreement with the immunostaining results portrayed in Figure 1. This synergistic reaction was specific for ICAM-1, as no change in KC HLA-DR expression was noted compared to the isotype control (portrayed by the open profile areas in the upper panels of Fig. 2). Figure 3 summarizes a representative experiment in which the effects of various concentrations of both TNF- $\alpha$ and histamine were used. Below $0.1 \mathrm{mM}$ histamine had no significant effect, but by $0.5 \mathrm{mM}$, a consistent increase in ICAM-1 expression was detected. As shown in the Figure 3C combining TNF- $\alpha$ (500 $\mathrm{U} / \mathrm{ml}$ ) with increasing concentrations of histamine resulted in a marked synergistic induction of $\mathrm{KC}$ ICAM-1. Similar FACS analysis failed to reveal any
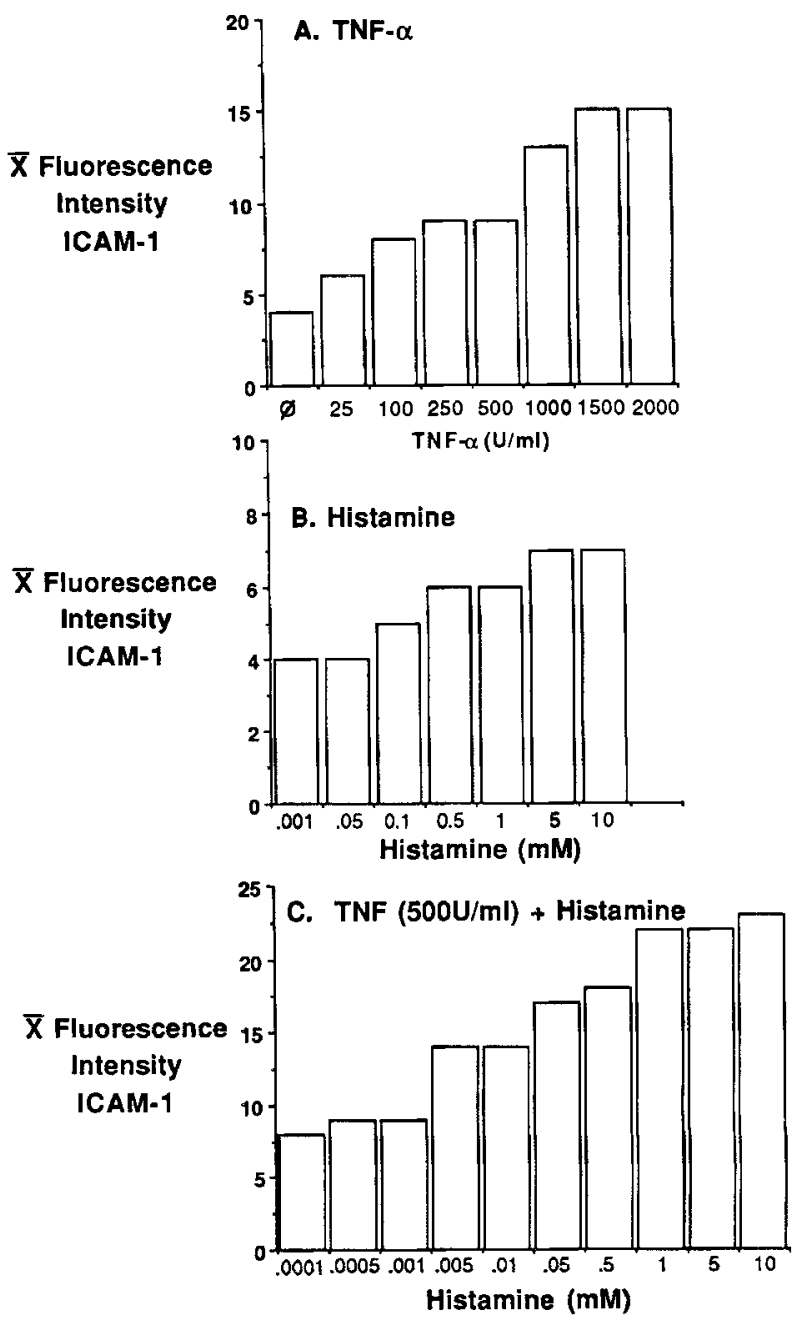

Fig. 3. Summary of mean channel fluorescence values for $\mathrm{KCs}$ treated with a range of concentrations of either TNF- $\alpha$ alone (A), histamine alone (B), or TNF- $\alpha(500 \mathrm{U} / \mathrm{ml})$ plus various concentrations of histamine (C).

influence on KC ICAM-1 (with or without TNF- $\alpha$ ) for the same four compounds described above by immunostaining (L-histidine, 1-methylhistidine, 3-methylhistidine, all-trans-UCA; data not shown). The ability of the cis-UCA preparation to induce ICAM-1 is shown in Figure 4. On the left side of Figure 4 is the concentration dependent induction of KC ICAM-1 by TNF- $\alpha$ (with untreated KC ICAM-1 expression in the open area). On the right side, KC ICAM-1 expression induced by either histamine $(5 \mathrm{mM})$ or cis-UCA is presented, both without or with TNF- $\alpha(500 \mathrm{U} / \mathrm{ml})$. The combination of histamine or cis-UCA with TNF- $\alpha$ (500 $\mathrm{U} / \mathrm{ml}$ ) produced approximately the same FACS profile as did the TNF- $\alpha(1,000 \mathrm{U} / \mathrm{ml})$ for ICAM-1 expression. The mean channel fluorescence intensity values are as follows: No TNF- $\alpha=3$; TNF- $\alpha(50 \mathrm{U} / \mathrm{ml})=9$; TNF- $\alpha$ $(100 \mathrm{U} / \mathrm{ml})=16 ; \mathrm{TNF}-\alpha(500 \mathrm{U} / \mathrm{ml})=26 ; \mathrm{TNF}-\alpha(1,000$ $\mathrm{U} / \mathrm{ml})=33$; histamine alone $(5 \mathrm{mM})=8$; cis-UCA alone $(2.4 \mathrm{mM})=7$; histamine plus TNF- $\alpha$ (500 $\mathrm{U} / \mathrm{ml})=38$; cis-UCA plus TNF- $\alpha(500 \mathrm{U} / \mathrm{ml})=35$. It 
ICAM-1 EXPRESSION

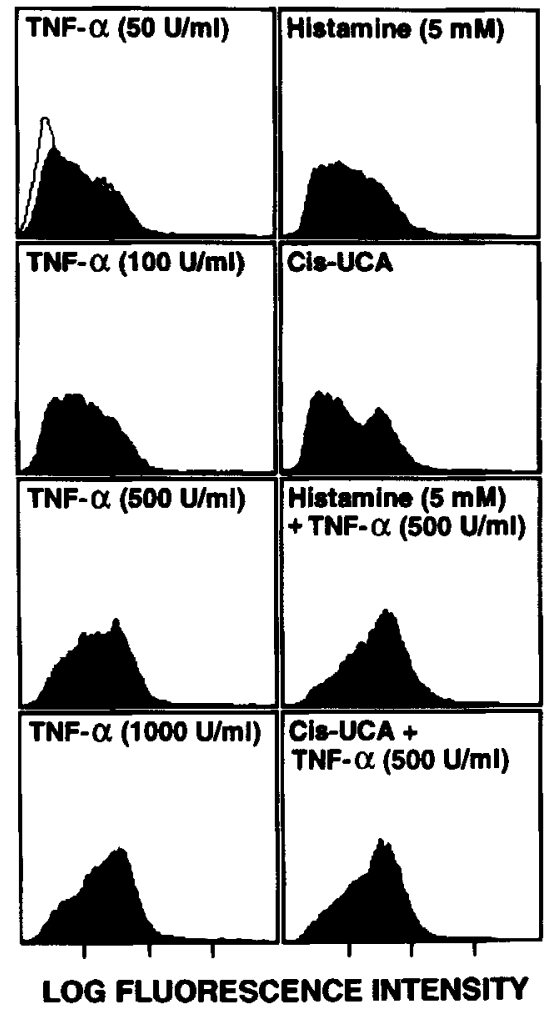

Fig. 4. FACS profile of KC ICAM-1 expression induced by various concentrations of TNF- $\alpha$ compared to histamine alone, cis-UCA alone, and combinations of histamine plus TNF- $\alpha$, and cis-UCA plus TNF- $\alpha$.

should be noted that these levels of ICAM-1 expression using TNF- $\alpha$ are relatively low compared to the ability of interferon gamma (IFN- $\gamma$ ) alone $(20 \mathrm{U} / \mathrm{ml})$ to induce ICAM-1 (value $=164$ ) in agreement with a previous report (Norris et al., 1990).

\section{Induction of KC ICAM-1 mRNA by Northern blot hybridization}

To determine whether the synergistic interaction between histamine and TNF- $\alpha$ with respect to $\mathrm{KC}$ ICAM-1 expression was related to transcriptional events, Northern blot hybridization studies were performed. As previously observed, KCs produce ICAM-1 mRNA transcripts after $6 \mathrm{hr}$ of stimulation with cytokines such as IFN- $\gamma$ and TNF- $\alpha$ (Fig. 5a). In untreated $\mathrm{KC}$ cultures, no significant ICAM-1 mRNA was detectable, and the IFN- $\gamma(500 \mathrm{U} / \mathrm{ml})$ induction of ICAM-1 mRNA served as a positive control. Using histamine alone at $0.05 \mathrm{mM}$ and $0.10 \mathrm{mM}$, no significant ICAM-1 mRNA was detectable in agreement with the cell surface detection by FACS analysis at the protein level (Eig. 3). Combining TNF- $\alpha(500 \mathrm{U} / \mathrm{ml})$ with histamine (0.05 or $0.1 \mathrm{mM}$ ) produced increased ICAM-1 mRNA compared to TNF- $\alpha$ alone. This augmentation in ICAM-1 mRNA was synergistic at the mRNA level (as determined by laser densitometry analysis of the Northern blot, Fig. 5b) which is in agreement with the protein expressed at the cell surface as detected by
FACS analysis. Cyclophilin mRNA results confirm equivalent loading of samples per well.

Figure 6 reveals that combining cis-UCA (1 mM) with TNF- $\alpha(500 \mathrm{U} / \mathrm{ml})$ also increased ICAM-1 mRNA above that induced by either molecule used signly. To determine whether the induction of KC ICAM-1 by histamine was related to increased $\mathrm{TNF}-\alpha$ production by $\mathrm{KCs}$, two experimental approaches were utilized. First, conditioned medium for KC supernatants was collected after 6 and $24 \mathrm{hr}$ of addition of histamine $(5 \mathrm{mM})$ to KGM. However, no TNF- $\alpha$ bioactivity was detected using a highly sensitive bioassay in the conditioned media before or after addition of histamine (data not shown). In the second approach, TNF- $\alpha$ mRNA transcripts were examined by northern blot hybridization. Figure 7 reveals that at 6 and $18 \mathrm{hr}$ after addition of histamine $(5 \mathrm{mM})$, no TNF- $\alpha$ transcripts were identified. As previously observed (Barker et al., 1990), TNF- $\alpha$ autoinduces the detection of TNF- $\alpha$ mRNA transcripts in cultured $\mathrm{KCs}$, and in some experiments the combination of histamine plus TNF- $\alpha$ further increased the detection of TNF- $\alpha$ mRNA transcripts. Whether this increased amount of TNF- $\alpha$ mRNA transcripts was accompanied by a concomitant increase in translated and secreted protein could not be determined because of the cross-reactivity in the bioassay between the added exogenous recombinant $\mathrm{TNF}_{-\alpha} \alpha$ and the naturally produced TNF- $\alpha$.

\section{Measurement of TNF- $\alpha$ surface receptors by ligand binding and FACS analysis}

To determine whether the marked increase in ICAM-1 induction was due to the alteration of TNF- $\alpha$ receptor number or affinity in the presence of histamine, surface binding of labeled TNF- $\alpha$ was next carried out. Figure 8 shows a time course of TNF- $\alpha$ binding to confluent cultures of $\mathrm{KCs}$ at $4^{\circ} \mathrm{C}$. Results show that specific binding (total binding minus nonspecific binding which was determined by including 200 -fold excess nonlabeled TNF- $\alpha$ ) reached a plateau between $8-12 \mathrm{hr}$ in agreement with a previous report (Pillai et al., 1989). At $37^{\circ} \mathrm{C}$, the maximal binding was achieved by $3 \mathrm{hr}$ (data not shown). However, at $37^{\circ} \mathrm{C}$, a considerable cell associated radioactivity was internalized (Pillai et al., 1989). Also the extent of degradation of labeled TNF- $\alpha$ was minimal at $4^{\circ} \mathrm{C}$ (Pillai et al., 1989). Hence, all the binding assays with ${ }^{125} \mathrm{I}-\mathrm{TNF}-\alpha$ were carried out at $4^{\circ} \mathrm{C}$ for 4-6 hr. KCs in culture treated with $5.0 \mathrm{mM}$ histamine for $48 \mathrm{hr}$, or untreated cultures were washed and used for ${ }^{125}$ I-TNF- $\alpha$ binding studies. The specific binding to $\mathrm{KCs}$ increased with increasing concentrations of labeled TNF- $\alpha$ and achieved saturation with and without histamine between 0.4 and $0.55 \mathrm{nM}$ (Fig. 9a). Using histamine at $5.0 \mathrm{nM}$ concentration which did not inhibit $\mathrm{KC}$ proliferation or alteration in morphology, no difference in ${ }^{125}$ I-TNF- $\alpha$ binding was observed (Fig. 9a). Scatchard plot analysis of the ligand binding data yielded linear plots (regression coefficient $=0.9$ ) indicating the presence of a single class of high affinity binding sites (Fig. 9b). The dissociation constant for histamine treatment or non-treated cell was calculated to be $0.25 \pm 0.03 \mathrm{nM}$ with $1,600 \pm 150$ receptor sites per KC. Neither the number of receptors per cell nor the affinity constant for TNF- $\alpha$ was altered by includ- 

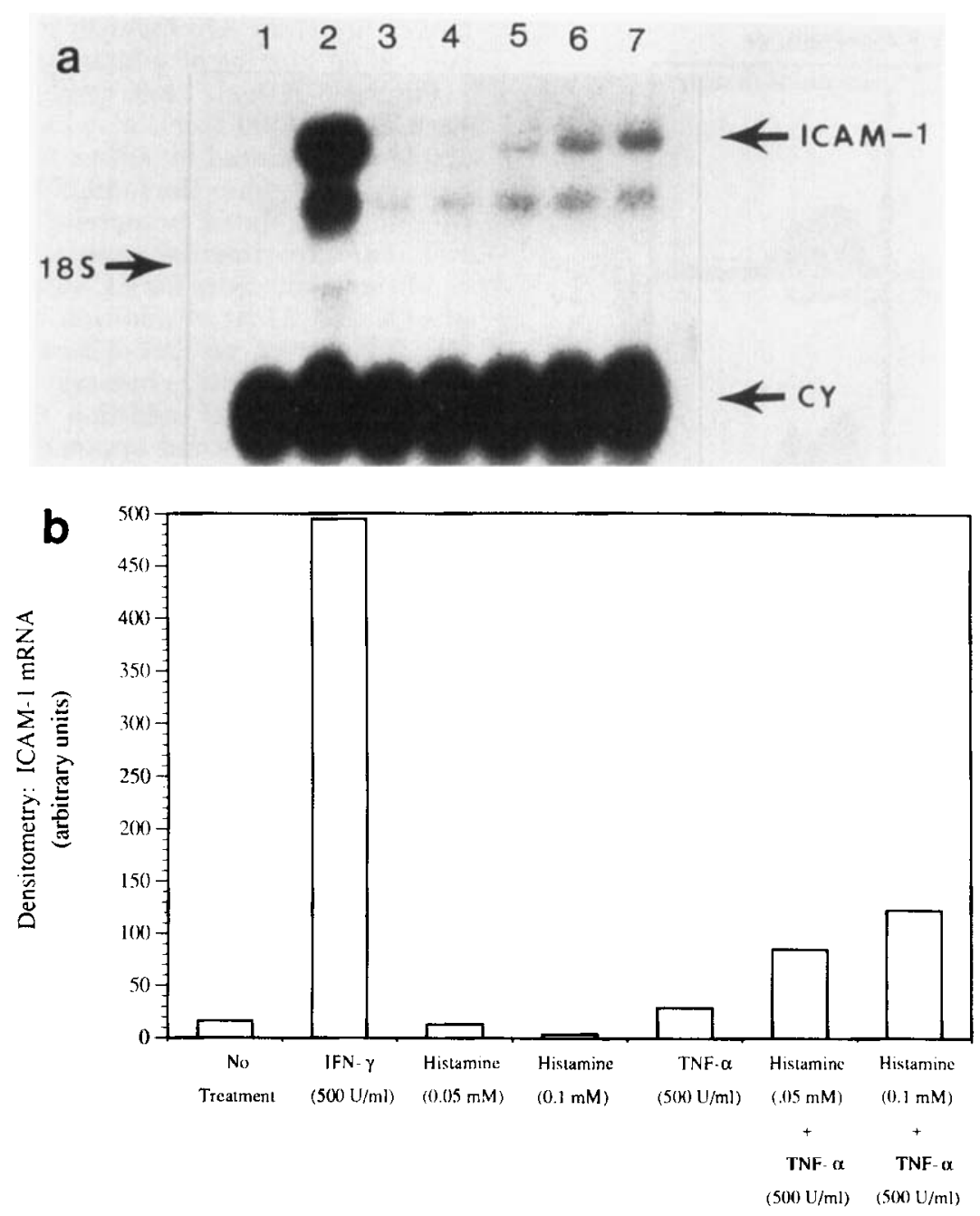

Fig. 5. a: Northern blot for KC ICAM-1 and cyclophilin (Cy) mRNA levels 6 hr after stimulation with either KGM alone (lane 1); $500 \mathrm{U} / \mathrm{ml}$ IFN- $\gamma$ (lane 2); $.05 \mathrm{mM}$ histamine (lane 3); $0.1 \mathrm{mM}$ histamine (lane 4); $500 \mathrm{U} / \mathrm{ml} \mathrm{TNF- \alpha} \mathrm{(lane} \mathrm{5);} .05 \mathrm{mM}$ histamine plus TNF- $\alpha$ (lane 6); or $0.1 \mathrm{mM}$ histamine plus TNF- $\alpha$ (lane 7). b: Relative density of the signals for each of the lanes of the Northern blot for ICAM-1 as determined by scanning laser densitometry.

ing $0.1 \mathrm{mM}$ histamine in binding assay medium or by exposing KCs to a much higher concentration of histamine such as $2 \mathrm{mM}$. By FACS analysis, $\mathrm{KC}$ cell surface immunostaining for the $55-60 \mathrm{kDa}$ TNF- $\alpha$ receptor revealed a single peak with a mean channel fluorescence value of 18 (isotype control value $=4$ ). Pretreating the $\mathrm{KCs}$ for $24 \mathrm{hr}$ with either histamine ( $5 \mathrm{mM}$ ) or cis-UCA (2.5 $\mathrm{mM}$ ) did not significantly change the FACS profile (data not shown).

\section{Characterization of ${ }^{\mathbf{3}} \mathbf{H}$-histamine binding to $\mathrm{KCs}$}

While histamine did not modulate the affinity or number of TNF- $\alpha$ receptors, we asked the reciprocal question; does TNF- $\alpha$ modulate histamine binding? Because no previous studies have been published detailing the ability of histamine to bind and stimulate $\mathrm{KCs}$, we explored appropriate ligand binding parameters using ${ }^{3} \mathrm{H}$-histamine. Uptake of histamine in KCs was observed when the binding studies were carried out at

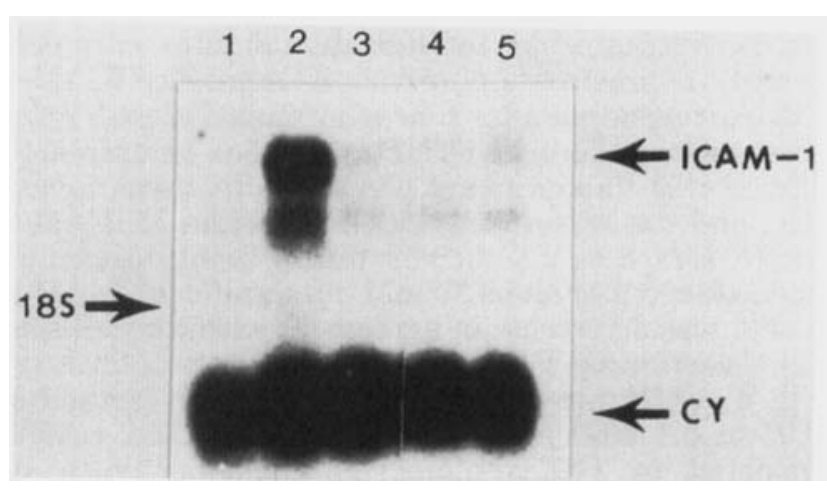

Fig. 6. Northern blot of KC ICAM-1 and cyclophilin mRNA levels 6 $\mathrm{hr}$ after stimulation with either KGM alone (lane 1); $500 \mathrm{U} / \mathrm{ml} \mathrm{IFN- \gamma}$ (lane 2); $500 \mathrm{U} / \mathrm{ml}$ TNF- $\alpha$ (lane 3); $1 \mathrm{mM}$ cis-UCA (lane 4); or cis-UCA plus TNF- $\alpha$ (lane 5). 


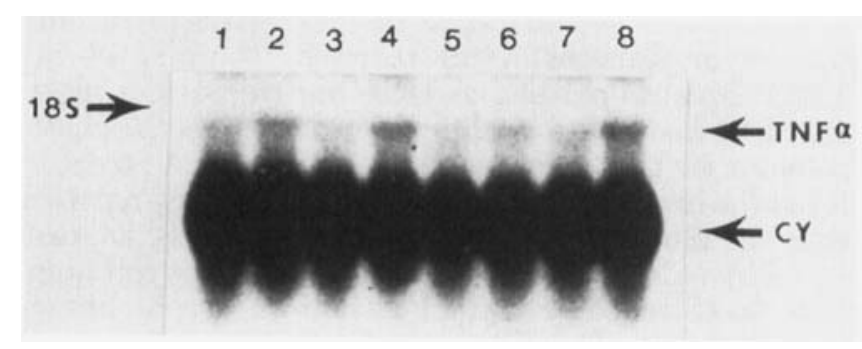

Fig. 7. Northern blot of KC TNF- $\alpha$ and cyclophilin mRNA levels 6 and $18 \mathrm{hr}$ after stimulation with either KGM alone (6 hr-lane 1; 18 hrr-lane 5); $500 \mathrm{U} / \mathrm{ml}$ TNF- $\alpha$ alone (6 hr-lane $2 ; 18 \mathrm{hr}$-lane 6$) ; 5 \mathrm{mM}$ ristamine alone ( $6 \mathrm{hr}$-lane $3 ; 18 \mathrm{hr}$-lane 7$)$; or histamine plus TNF- $\alpha$ (is hr-lane 4; 18 hr-lane 8).

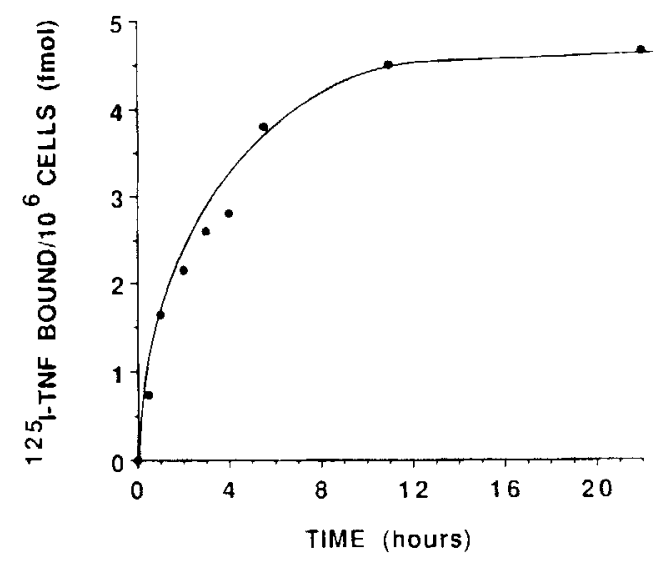

Fig. 8. Time course for ${ }^{125} \mathrm{I}-\mathrm{TNF}-\alpha$ bind to $\mathrm{KCs}$ at $4^{\circ} \mathrm{C}$.

$37^{\circ} \mathrm{C}$ and in the presence of high concentrations of serum $(20 \%)$, as the binding of $\left[{ }^{3} \mathrm{H}\right]$ histamine was extremely low at $4^{\circ} \mathrm{C}$ and lower concentrations of serum resulted in a significant nonspecific binding (data not shown). The presence of $20 \%$ fetal calf serum in the KGM incubation is sufficient to reduce the nonspecific binding to a level of $30-40 \%$. A high level of nonspecific binding has been reported (Haddock et al., 1987) when $\left[{ }^{3} \mathrm{H}\right]$ histamine uptake was studied with human vascular endothelial cells.

KCs were incubated with $0.03 \mu \mathrm{M}\left[{ }^{3} \mathrm{H}\right]$ histamine in the presence of different concentrations of unlabeled histamine and cell associated radioactivity was determined. The results of competition analysis demonstrate the specificity of binding between unlabeled and labeled histamine (Table 1). At $200 \mu \mathrm{M}$ of unlabeled histamine, the binding was reduced by $70 \%$. Table $1 \mathrm{com}-$ pares the influence of TNF- $\alpha$, diphenhydramine $\left(\mathrm{H}_{1}\right.$ antagonist), and cimetidine $\left(\mathrm{H}_{2}\right.$ antagonist) on $\left[{ }^{3} \mathrm{H}\right]$ histamine uptake. With TNF- $\alpha$ pretreated KCs $(500 \mathrm{U} / \mathrm{ml}$ for $24 \mathrm{hr}$ ), or inclusion of TNF- $\alpha$ in the binding medium, no difference in $\left[{ }^{3} \mathrm{H}\right]$ histamine uptake was observed in comparison with untreated cultures. It thus appears that the TNF- $\alpha$ does not modulate the affinity or number of histamine receptors. Inhibition of uptake of labeled histamine by cimetidine in KCs indicates that the $\mathrm{H}_{2}$ type of the histamine receptor is predominantly in-
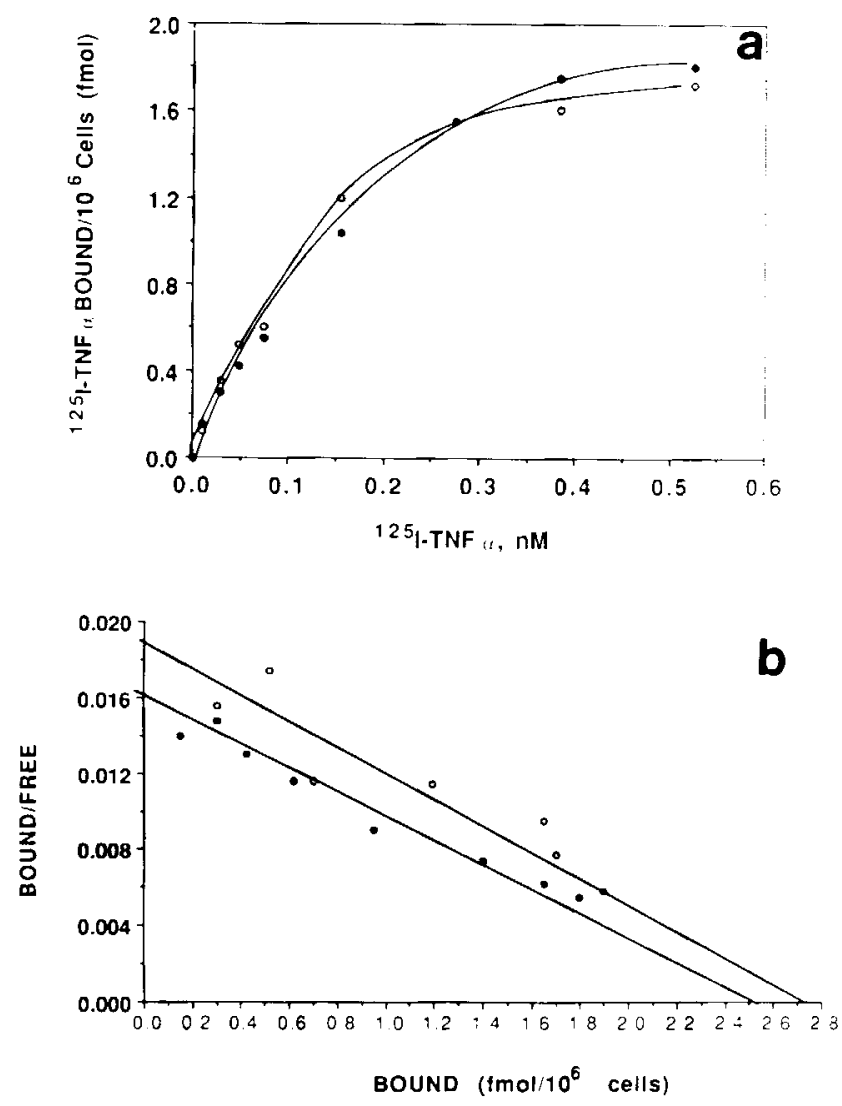

Fig. 9. a: Concentration dependent binding of ${ }^{125} \mathrm{I}-\mathrm{TNF}-\alpha$ to $\mathrm{KCs}$ maintained either in KGM (closed circles) or treated for $48 \mathrm{hr}$ with histamine ( $5 \mathrm{mM}$; open circles). b: Scatchard analysis of ligand binding data reveals a single class of high affinity TNF- $\alpha$ receptors which is not significantly influenced by exposure to histamine.

volved. In contrast, the inability of the antagonist diphenhydramine to inhibit labeled histamine uptake by $\mathrm{KCs}$ suggests that $\mathrm{H}_{1}$ receptors do not play a significant role in the observed uptake. Failure to inhibit the uptake of $\left[{ }^{3} \mathrm{H}\right]$ histamine by all-trans-UCA or its cis isomer even at higher concentration indicates that UCA uptake in KCs is not mediated through the histamine receptor.

\section{DISCUSSION}

The earliest inflammatory and immunological responses in skin can be viewed as the result of a cascade of molecular mediators produced by several different resident cell types. In this study, we focused on three such mediators produced by KCs and/or mast cells; i.e., TNF- $\alpha$, UCA, and histamine. TNF- $\alpha$ is being recognized as a key cytokine in several common cutaneous disorders such as allergic and irritant contact dermatitis, and in UV-B induced tolerance to epicutaneous haptens (Barker et al., 1991; Griffiths et al., 1991; Piquet et al., 1991; Vermeer and Streilein, 1990). While a previous study suggested that mast cell derived proinflammatory mediators together with TNF- $\alpha$ were important in the development of a cellular inflammatory response (via induction of endothelial cell adhesion molecules), it was not clear whether histamine and TNF- $\alpha$ could syn- 
ergize in such reactions (Klein et al., 1989). Moreover, while the rapidly evolving dissection of the immunomodulatory properties of UV-B have increasingly centered on TNF- $\alpha$, and the isomerization of all-transUCA to cis-UCA (reviewed in Noonan and DeFabo, 1992), no previous study specifically addressed whether cis-UCA plus TNF $-\alpha$ could augment KC ICAM-1 expression.

The current data indicate that both histamine and cis-UCA can directly induce KC ICAM-1 expression, albeit rather weakly in comparison with either TNF- $\alpha$ or IFN- $\gamma$. However, both histamine and cis-UCA, when combined with TNF- $\alpha$, signifícantly augment KC ICAM-1 expression (at the mRNA and protein level), without influencing class II MHC (i.e., HLA-DR) expression. Other histamine related compounds such as L-histidine, 1-methylhistidine, 3-methylhistidine, and all-trans-UCA lacked any capacity, when used either singly or in combination with TNF- $\alpha$, to influence KC ICAM-1 expression. The interaction between histamine and cis-UCA with TNF- $\alpha$ did not involve detectable changes in either the number or affinity of either the TNF- $\alpha$ receptor or the histamine receptor. TNF- $\alpha$ receptor expression was characterized by both ligand binding with Scatchard analysis, as well as by flow cytometry. The affinity constant and number of receptors determined in our laboratory $(0.25 \mathrm{nM} ; 1,600$ sites per cell) are in good agreement with a previous group of investigators ( $0.28 \mathrm{nM} ; 1,250$ sites per cell; Pillai et al., 1989), as was our cell surface immunodetection for the epithelial type (i.e., $55-60 \mathrm{kDa}$ ) of the $T \mathrm{NF}_{-\alpha}$ receptor (Hohmann et al., 1989; Trefzer et al., 1991). The ability of histamine to induce ICAM-1 expression was not accompanied by any detectable increase in $\mathrm{KC}$ production of TNF- $\alpha$ as measured at the mRNA or functional protein level in the conditioned medium. However, it is possible that both histamine and cis-UCA can induce a small increase in TNF- $\alpha$ which immediately bound to unoccupied high affinity cell surface receptors. Experiments utilizing polymerase chain reaction technology to detect relatively small changes in transcriptional events may be useful in this regard. It should be noted that a previous group investigating the action of IFN- $\gamma$ plus TNF- $\alpha$ also could not correlate the synergistic response of the KCs to IFN- $\gamma$ with any detectable change in TNF- $\alpha$ receptor expression (Trefzer et al., 1991).

With respect to the KC cell surface receptors for histamine, it appears that $\mathrm{KCs}$ possess a type 2 receptor because ${ }^{3} \mathrm{H}$-histamine binding was inhibited by cimetidine (an $\mathrm{H}_{2}$ receptor antagonist) but not by diphenhydramine (an $\mathrm{H}_{1}$ receptor antagonist). The functional response of some cell types bearing $\mathrm{H}_{2}$ receptors involves activation of phospholipase $\mathrm{C}$ (reviewed in Mitsuhashi and Payan, 1992) and we have previously observed that ICAM-1 but not HLA-DR can be induced by phorbol ester which is a protein kinase $\mathrm{C}$ activator (Griffiths et al., 1990). Thus, histamine may augment TNF- $\alpha$ mediated ICAM-1 expression by postreceptor binding events such as second messenger systems involving phospholipase $\mathrm{C}$ /protein kinase $\mathrm{C}$. Moreover it appears that with monocytes, histamine can suppress TNF- $\alpha$ production via $\mathrm{H}_{2}$ receptors, and this may serve as a negative feedback loop to prevent excessive TNF- $\alpha$ production by both recruited blood derived monocytes, as well as KCs within a skin site undergoing an inflammatory or immunological reaction (Vannier et al., 1991). Because neither cis-UCA nor trans-UCA influenced ${ }^{3} \mathrm{H}$-histamine binding, it appears that the photoreceptor for UV-B light on KCs (i.e., cis-UCA receptor) is not the histamine receptor. A previous study reported that the immunosuppressive effects of UV-B, as measured by reduction in epidermal Langerhans cell numbers, was blocked by a type 1 histamine receptor antagonist such as terfenadine, as well as by a type 2 receptor antagonist such as cimetidine (Norval et al., 1990). Thus, Langerhans cells may possess a histamine-like photoreceptor for UCA different from the KC photoreceptor, which is not influenced by histamine receptor antagonists.

Our data indicate that during the evolution of a cutaneous inflammatory reaction, important cross-talk may occur between epidermal KCs and dermal mast cells involving soluble mediators such as TNF- $\alpha$, histamine, and cis-UCA. Based on our earlier hypothesis for cutaneous reactions (Barker et al., 1990), the early initiation phase can now be viewed as resulting from TNF- $\alpha$ plus the enhancing effects of histamine and cisUCA for the up-regulation of KC ICAM-1. However, as pointed out in the original hypothesis, the subsequent amplification phase, which features the involvement of T-cell derived IFN- $\gamma$, represents a substantially more potent cytokine for the further induction of $\mathrm{KC}$ ICAM-1. With respect to two common T-cell mediated diseases exacerbated by bacterial infections such as psoriasis and atopic dermatitis that feature mast cells and cytokine activated $\mathrm{KCs}$, we have recently observed that KCs can present bacterial derived superantigens to resting T cells (Nickoloff et al., 1992). This autologous T-cell response was inhibited by antibodies directed against the CD-11a/CD-18 antigens on T cells and ICAM- 1 on KCs. Thus, the ability of histamine and cis-UCA to augment TNF- $\alpha$ inducible KC ICAM-1 expression may convey critically important immunomodulatory signals to both $\mathrm{KCs}$ and $\mathrm{T}$ cells recruited from the circulation during inflammatory reactions of the skin. Additional additive, synergistic, and antagonistic functional interactions among these three key mediators of inflammatory and immune reactions need to be investigated in other cutaneous cell types beyond $\mathrm{KCs}$, and in a range of skin diseases, to more fully assess the potential therapeutic impact of these current in vitro results.

\section{ACKNOWLEDGMENTS}

The authors thank Y. Naidu for assistance with the scanning laser densitometry measurements to quantitate mRNA levels. This work was supported by NIH grants AR 38957, 40065, 40488 (B.J.N.), and AI 31126 (Y.S.).

\section{LITERATURE CITED}

Baden, M.P., Pathak, M.A., and Butler, D. (1966) Trans to cis isomerization of urocanic acid. Nature, 210:732-733.

Barker, J.N.W.N., Sarma, V., Dixit, V., and Nickoloff, B.J. (1990) Marked synergism between tumor necrosis factor-alpha and interferon-gamma in regulation of keratinocyte derived chemotactic and adhesion molecules. J. Clin. Invest., 85:605-608.

Barker, J.N.W.N., Mitra, R.S., Griffiths, C.E.M., Dixit, V.M., and Nickoloff, B.J. (1991) Keratinocytes as initiators of inflammation. Lancet, $337: 211-214$. 
Dale, H.H. (1929) Some chemical factors in the control of the circulation: Local vasodilator reactions-histamine. Lancet, 1:1233-1237.

Eskandari, M.K., Nguyen, D.T., Kunkel, S.L., and Remick, D.G. (1990) WEHI 164 subclone 13 assay for TNF: Sensitivity, specificity, and reliability. Immunol. Invest., 19:69-79.

Falus, A., and Meretey, K. (1992) Histamine-An early messenger in inflammatory and immune reactions. Immunol. Today, 13:154-156.

Griffiths, C.E.M., and Nickoloff, B.J. (1989) Keratinocyte intercellular adhesion molecule-1 (ICAM-1) expression precedes dermal T lymphocytic infiltration as allergic contact dermatitis (rhus dermatitis). Am. J. Pathol., 135:1045-1053.

Griffiths, C.E.M., Voorhees, J.J., and Nickoloff, B.J. (1989) Gamma interferon induces different cellular patterns of expression of HLA-DR and -DQ and intercellular adhesion molecule-1 antigens. Br. J. Dermatol., 120:1-7.

Griffiths, C.E.M., Esmann, J., Fisher, G.J., and Nickoloff, B.J. (1990) Gamma interferon differentially modulated keratinocyte expression of HLA-DR and intercellular adhesion molecule-1 (ICAM-1): Evidence for a protein kinase $C$ independent and independent pathway. Br. J. Dermatol., 122:333-342.

Griffiths, C.E.M., Barker, J.N.W.N., Kunkel, S., and Nickoloff, B.J (1991) Induction, distribution, and diminution of leukocyte adhesion molecules (ELAM-1, VCAM-1, ICAM-1), T cell chemotaxin (IL-8) and a modulatory cytokine (TNF- $\alpha$ ) during the evolution of allergic contact dermatitis (rhus dermatitis). Br. J. Dermatol., 124:519-526.

Haddock, R.C., Mack, P., Fogerty, F., and Baenziger, N.L. (1987) Role of receptors in metabolic interaction of histamine with human vascular endothelial cells and skin fibroblasts. J. Biol. Chem., 262:10220-10228.

Hohmann, H.P., Remy, R., Brockhaus, M., and VanLoon, A.P. (1989) Two different cell types have different major receptors for human tumor necrosis factor (TNF- $\alpha$ ). J. Biol. Chem., 264:14927-14934.

Klein, L.M., Lavker, R.M., Matis, W.L., and Murphy, G.F. (1989) Degranulation of human mast cells induces an endothelial antigen central to leukocyte adhesion. Proc. Natl. Acad. Sci. USA, 86:89728976.

Lewis, T. (1927) The Blood-Vessels of the Human Skin and Their Response. Shaw and Sons, London.

Mitsuhashi, M., and Payan, D.G. (1992) Functional diversity of histamine and histamine receptors. J. Invest. Dermatol. (suppl) 98:8-11.

Nickoloff, B.J. (1992) Role of epidermal keratinocytes as key initiators of contact dermatitis due to allergic sensitization and irritation. Am. J. Contact Dermatitis 3:65-69.

Nickoloff, B.J., Mitra, R.S., Green, J., Shimizu, Y., Thompson, C., and Turka, L. (1992) Gamma interferon treated keratinocytes present bacterial derived superantigens to $\mathrm{T}$ cells which is blocked by LFA1/ICAM-1 antibodies (abstract). Clin. Res., 40:720.

Noonan, F.P., and DeFabo, E.C. (1992) Immunosuppression by ultraviolet $\mathrm{B}$ radiation: Imitation by urocanic acid. Immunol. Today, $13: 250-254$.

Norris, D.A., Lyons, M.B., Middleton, M.H., Yohn, J.J., and Kashihara-Sawani, M. (1990) Ultraviolet radiation can either suppress or induce expression of intercellular adhesion molecule-1 on the surface of cultured human keratinocytes. J. Invest. Dermatol., 95:132138.

Norval, M., Gilmour, J.W., and Simpson, T.J. (1990) The effect of histamine receptor antagonists on immunosuppression by the cisisomer of urocanic acid. Photodermatol. Photoimmunol. Photomed. $7: 243-248$

Pillai, S., Bikle, D.D., Eessalin, T.E., Aggarwal, B.B., and Elias, P.M. (1989) Binding and biological effects of tumor necrosis factor alpha on cultured human neonatal foreskin keratinocytes. J. Clin. Invest., 83:816-821.

Piquet, P.F., Grau, G.E., Hauser, C., and Vassalli, P. (1991) Tumor necrosis factor is a critical mediator in hapten-induced irritant and contact hypersensitivity reactions. J. Exp. Med, 173:673-679.

Ross, J.A., Howie, S.E.M., Norval, M., Maingay, J., and Simpson, T.J. (1986) Ultraviolet-irradiated urocanic acid suppresses delayed-type hypersensitivity to herpes simplex in mice, J. Invest. Dermatol., $87: 630-633$

Trefzer, U., Brockhaus, M., Loetscher, H., Parlow, F., Kapp, A., Schopf, E., and Krutmann, J. (1991) 55-Kd tumor necrosis factor is expressed by human keratinocytes and plays a pivotal role in regulation of human keratinocyte ICAM-1 expression. J. Invest. Dermatol., 97:911-916.

Vannier, E., Miller, L.C., and Dinarello, C.A. (1991) Histamine suppresses gene expression and synthesis of tumor necrosis factor- $\alpha$ via histamine $\mathrm{H}_{2}$ receptors. J. Exp. Med, 174:281-284

Vermeer, M., and Streilein, J.W. (1990) Ultraviolet-B light induced alterations in epidermal Langerhans cells are mediated by tumor necrosis factor-alpha. Photodermatol. Photoimmunol. Photomed. $7: 258-265$. 